\title{
SOME REFORMS IN OUR SYSTEM OF MILITARY JUSTICE
}

\author{
S. T. ANSELI
}

\section{I}

No changes of a truly organic character took place in our system of military justice from the time we adopted it from the British upon our separation until the enactment of the new Articles of War by Congress two years ago. An appreciation of the character of these changes wrought by that organic act necessitates an examination into the military code as we took it over upon the outbreak of the Revolution and from that day on inertly let it remain without systemic change until the bill to modernize and liberalize our Articles of War was enacted as Chapter II of the National Defense Act of June 4, I920, retaining its title as an Act "to establish military justice." 1

It is an historical fact, a condition that could not have so long endured but for our national lack of interest in military matters in general and our professional unconcern with military law in particular, that up to this recent enactment of the new Articles of War, our military code organically and for the most part in faithful detail was the British Articles of 1774 , themselves of much more ancient origin. That this was true our military historians and military-law authorities, with their love for ancient lineage in such things, were accustomed proudly to declare; at least, up to I9I8, when our archaic articles, subjected to a severe fire of just criticism, became difficult to defend. The various British codes, including the one of 1774 taken over by us, came from the Continent and in letter and substance can be traced to Rome. Beginning with the Articles of Richard II, in 1385 , a comparison of the several British codes will show that at the time of our Revolution they had changed little or none in system, principle, or procedure. The code of 1774 , adopted in its entirety by our Continental Congress of I775, breathed the spirit and spoke the language of the Code of Richard II and of its ancient continental prototypes.

At the outbreak of the Revolution, these Romano-British articles were the only code available to us, and in the face of the emergency Congress adopted them. This it did largely at the instance of John Adams, who himself said: ${ }^{2}$

"There was extant one system.of articles of war which had carried two empires to the head of mankind, the Roman and the British; for

[In connection with the above article, see Edmund M. Morgan, The Existing Court-Martial System and the Ansell Army Articles (19rg) 29 Yale Law JoURNAL, 52. Ed.]

${ }^{1} 4$ I Stat. at L. 759,787 (italics ours).

3 Works of John Adans (I85I) 68. 
the British articles of war were only a literal transiation of the Roman. It would be vain for us to seek in our own inventions, or the records of warlike nations, for a more complete system of military discipline..... I was, therefore, for reporting the British articles of war, totidem verbis."

He himself appreciating their rigorous character, hardly expected them to be adopted at all, and certainly not without substantial, probably radical, liberalization, for he said: ${ }^{3}$

"It was a very difficult and unpopular subject, and I observed to Jefferson, that whatever alteration we should report with the least energy in it or the least tendency to a necessary discipline of the Army would be opposed with as much vehemence, as if it were the most perfect; we might as well, therefore, report a complete system at once, and let it meet its fate. Something perhaps might be gained."

Writing years later he took occasion to express his surprise in this language: ${ }^{4}$

"So undigested were the notions of liberty prevalent among the majority of the the members most zealously attached to the public cause, that to this day I scarcely know how it was possible that these articles could have been carried. They were adopted, however, and they have governed our armies with little variation to this day."

These ancient un-American articles, thus adopted to meet the emergency, were kept without substantial change throughout the Revolution, and when the war was over and the army was disbanded none gave further thought to them. In our first war, as in our latest, and in all the years of our national existence between, we were true to Arkansas-Traveller philosophy: when war was on we could not change the Articles and when it was over we no longer needed them. These Romano-British articles were continued in force before and for many years after the inauguration of the government under the constitution by successive statutes perfunctorily enacted to that end, and survived the adoption of the constitution by this simple expedient. True, in I806, the Articles were re-enacted," but "with only such modifications as were necessary to adapt them [that is, verbally] to the Constitution of the United States"; ${ }^{\circ}$ and this re-enactment itself from I806 until the enactment of the new Articles of 1920 underwent only minor modifications. In I9I2 the Judge Advocate General in advocating a "revision" of these articles - since styled the "19r6 revision"] - which was but a restatement of them for the purpose of "better arrangement and classification," said to the committees of Congress :

\footnotetext{
${ }^{3}$ Ibid.

Ibid. 83 .

${ }^{5}$ Act of April 10, 1806 (2 Stat. at L. 359).

${ }^{\circ}$ Hearing before the Committee on Military Affairs, H. R. 6ad Congress, ad Session, .0n H. R. 23628 (xor2) I6.

"Act of Aug. 29, I9I6 (39 Stat. at L. 619, 650).

${ }^{8}$ Hearing before the Committee on Military Affairs, op cit. I7.
} 
"It is to be doubted if the Congress has ever been called upon to amend legislation which is as archaic in its character as our present Articles of War."

Speaking at the same hearings of the fact that our articles had undergone no organic change since our separation from England, he quite correctly said : ${ }^{8}$

"Meantime, the British code, from which, as we have seen, these articles were largely taken, has been, mainly through the medium of the army annual act, revised almost out of recognition, indicating that the Government with which the code originated has recognized its inadaptability to modern service conditions."

The principal purpose ascribed to the revision of I9I6 was not to make any substantial change in the system but instead to cure the "notorious unsystematic and unscientific" form and arrangement of the articles. Even if more had been sought, it probably could not have been had. Certain it is that the I9I6 revision attempted nothing more and achieved nothing more, the Judge Advocate General assuring the committees in these words: $:^{10}$

"If Congress enacts this revision, the service will not be cognizant of any material changes in the procedure, and courts will function much the same as heretofore.... The revision will make certain a great deal that has been read into the existing code by construction."

So, unbelievable as it may seem, the United States upon entering the World War had for the just government and enlightened discipline of its army of citizen soldiers the system, principles, and much of the procedure of the mediaeval Romano-British code, a code which Britain, coming to recognize its utter inadaptability to service conditions, as they even then obtained, had largely cast aside a century before; one of the many examples of our regarding English law prototypes as sacrosanct long after they have outlived their usefulness in the land of their origin.

$$
\text { II }
$$

The military code, then, ours as an incident of emergent circumstance rather than the result of free intelligent consideration, came out of a theory of government at utter variance with the American conception generally, and at no point more so than in the matter of the source of authority for and the matter of maintaining, regulating, and controlling the military establishment. This will become obvious as a legal fact by contrasting the Royal Ordinances at the base of this British code and the pertinent provisions of our constitution. According to the principles of these ancient ordinances the army was the army of the King to be disciplined by him and his commanders under his ordinances and at his pleasure, whereas our constitution provides that ${ }^{11}$ "the Congress shall have [exclusive] power" (a) "to raise and support Armies," and (b)

Ibid. 5 .

${ }^{10} \mathrm{Ibid} .43$.

II United States Const. (I789) art. I, sec. 8. 
"to make Rules for the Government and Regulation of the land and naval Forces." But, by reason of the circumstances we have just seen, we had until I920 a British royal-prerogative military code congressionally prescribed, and with that ancient ill-adapted code we entered upon the recent war. There were some who, while it was yet time, appreciated the necessity and had in mind the measures for modifying the code so as to make it apply to our modern army with justice and efficiency, but it is as remarkable as regrettable that the "inadaptability" of such a code to our army of four million American freemen called to serve the nation as soldiers came to be authoritatively acknowledged only after the war was over, and reluctantly acknowledged even then.

By contrasting the principles expressed in the above fundamental provisions we can clearly see what kind of military code we did have and what kind we ought to have had. The one clearly represents the monarchical personal-government point of view; the other our theory that the representatives of the people should be the source of our military authority. Under the one the army is the army of a person in supreme authority, under the other it is an institution ordained by the people to do their service; under the one the obligation of the soldier is to a military chieftain, under the other to the state; under the one military relations are governed solely by considerations of personal fealty, under the other they are obligations established by law having its source not within the institution itself but in the common authority for the government of all. Under the former theory the King not only commanded but legislated for the army; prescribed the Articles of War, the offenses and the penalties, the substantive and procedural law, the courts-martial, and their jurisdiction; controlled the system of discipline and the methods of its administration. The army was his army, the officers his officers drawing their authority from him; courts-martial were his courts-martial, representing him and his power of command, applying his law, meting out his penalties, following his procedure and obeying his commands. Under such a scheme a court-martial was, as it was said then of the King and in our day of our superior commanders, "his right hand for the purpose of maintaining his discipline." Courtsmartial were, therefore, but agencies of the power of command to do the bidding of the commander, answerable to him and to no other law. True, administrative decisions and departmental practices of our service had modified to some extent the original character of this code but its underlying principles has not been disturbed. It was in the light of these un-American principles that all substantive laws were construed and applied and the substantial processes of military justice governed.

\section{III}

Accordingly, the following fundamental principles were deeply imbedded in our system of military justice: (I) Courts-martial were not courts of law at all, but simply agencies of the military commanders designated to convene them. (2) Being but military agencies-"the 
right hand of the commander" for the purpose of enforcing disciplinecourts-martial were creatures of the power of command and subject to that power in all that they did. (3) The commander convening courtsmartial was the final authority over their conduct and decisions, there being no room in such a system for a court of review for errors of law. These fundamental concepts put into action logically resulted in the following vices (or virtues, depending on the point of view) :

(I) A commissioned officer only could prefer charges for trial by. courts-martial; an enlisted man could not.

(2) The charge, simply signed by a commissioned officer but not sworn or even certified to, was sufficient to start the court-martial machinery in operation against the accused.

(3) The power of the commanding officer to convene courts-martial and subject any member in his command to trial was without legal limitation or restraint.

(4) No preliminary investigation was required to determine whether there was reasonable cause for the trial of the accused.

(5) The commanding officer, upon receiving the charges, could order the arrest or confinement of the accused and keep him in that status without trial, without being called to effective account.

(6) The commanding officer selected the members of the courtmartial which the accused could challenge only for cause and one at a time, the challenge being tried by the other member.

(7) The commanding officer, or a subordinate, appointed for the accused any military counsel he desired, not the accused himself, the wishes of the latter governing only when convenient.

(8) The commanding officer determined with finality all questions of law arising at or out of the trial, the sufficiency of the charge, the validity of all pleas and of the findings and sentence.

(9) In time of war, penalties were not prescribed by law but were left to be determined in each case by the court-martial in its ungoverned discretion.

(Io) Members of a court-martial, subject to the control of the commanding officer, were judges both of fact and law, in which latter capacity they could be advised, if they so requested, by the trial judge advocate (the prosecuting attorney).

(II) The commanding officer could overrule the decision of the court-martial favorable to the accused on any plea or other issue of law before them and order the court-martial to proceed in accordance with his view.

(I2) The commanding officer, disagreeing with the finding of the court-martial, even a finding of "not guilty," could, and frequently did, and as many times as he pleased, order the court-martial to reconvene and reconsider its decision for the purpose of revising it to conform to his view, and at such proceedings in revision the accused was not to be present or heard.

(13) The commanding officer's unregulated decision was final, beyond all power of modification except by the President's power of pardon.

The common law that grew up by administrative decision around such an un-American system could hardly be expected to reflect, nor did it, those principles of fairness and justice that characterize and are implied 
in any full and fair hearing under Anglo-American law. In a courtmartial, a mere military agency, an accused person found himself, according to the established view, entitled to none of the fundamental safeguards of a trial except in the instances where Congress had specifically legislated them upon him. The right to counsel and witnesses were but "privileges" that could be denied, and even the constitutional provision against double jeopardy was held to have no application to courts-martial until the Supreme Court in 1906 declared the contrary and left the War Department no room for a different view or a way around. ${ }^{12}$

\section{IV}

The results of this system during the war are, to a limited degree at least, matters of general knowledge. Tens of thousands of men were tried who, had there been a preliminary investigation, would not have been tried at all; thousands of men were tried and given shockingly. severe sentences for trivial infractions of military discipline due to ignorance rather than wrong intent, and thousands of innocent men were convicted and punished. Injustice was the inevitable result of such a system, but, contrary to what many were led to believe, the system resulted in less injustice during the war than would have followed normally by reason of extra-legal ameliorating and corrective agencies of an advisory character which were administratively created during the war in the office of the Judge Advocate General and which are now established permanently and endowed with authority by the new Articles of War.

Remedial legislation could not be had in the face of departmental opposition. Nevertheless throughout the war those who saw the daily grist of injustice pointed out from time to time, in official memoranda and otherwise, vices which they aptly characterized as "destructive of every assurance of justice," and finally submitted to the War Department and to Congress their views in a bill designed to establish military justice, which were the bases of the new Articles of War. The bill was prefaced by the following statement of its principles and specific provisions : ${ }^{13}$

\section{(I) GENERAL PRINCIPLES}

"The primary principle of this Bill is to establish Military Justice, and regulate it by Law rather than by mere Military Command; or, stating it differently, to supersede personal Military Power over Military Justice by Public Law. Law, to be effective for this purpose, must be law in its primary sense-a rule established beyond the control of the Department and the Army which are to administer it.

"Accordingly, this bill, designed to cure the vices of the existing system and to establish military justice upon the firm foundations indicated, is built upon the following basic considerations:

"(I) It proceeds in furtherance of the fundamental theory that

${ }^{12}$ Grafton v. United States (I906) 206 U. S. 333, 27 Sup. Ct. 749.

${ }^{23}$ Senate Committee Print of S. 64, 66th Congress, Ist Session (I919) 2 et seq. 
courts-martial are inherently courts, their functions inherently judicial, and that their powers must be judicially exercised, and it discountenances and penalizes a disregard of the sacred character of these judicial duties and functions.

"(2) It requires that the fundamental principles of right and justice declared to be such by our law and established as necessary to a full, fair, and impartial trial, shall be recognized and observed throughout the court-martial proceeding from accusation to execution.

"(3) It abolishes the present intolerable delegations of penal power and instead of leaving the military commander largely at liberty to determine the offense, the punishment, and the procedure, establishes these elements with that definiteness and precision which should characterize the exercise of all penal power.

"(4) It endeavors to provide that military punitive action be buttressed in enlightened concepts of justice, be regulated by the principles of justice, and that it give results that can fairly be accepted as justice.

"(5) It obstructs a hasty resort to punitive methods, withholds the hand of the commander who would be arbitrary, and stays the power of military authority that it may be exercised considerately and guided advisedly.

"(6) It proceeds upon the principle that military authority itself is subject to the demands of justice, and endeavors to reestablish in the Army a respect for, as it requires an observance of, those methods and processes which are necessary to justice.

"( 7$)$ It has regard for the fact that our soldiers are citizens; that the military status is but an incident of citizenship and that to it the rights of the citizen should not be tunnecessarily sacrificed.

"(8) It regards grade in the Army as a requisite of authority only, and not as marking a caste with established rights of preferment in matters of justice.

"(9) It abolishes star-chamber methods of court-martial procedure and declares the records to be public records accessible to the public as such."

\section{(II) SPECIFIC PROVISIONS}

"More specifically, the Bill is characterized by the following:

"(I) A charge must be preferred under a special sense of responsibility evidenced by an oath, and it may be preferred by a soldier as well as by an officer.

"(2) A thorough investigation must be made in which both sides shall be heard before the charges are preferred or forwarded for trial.

"(3) The restraining tendencies established are such as to prevent the trial of trivial charges, to compel a resort to the inferior courts rather than go to the general court, and to preserve discipline with fewer trials.

"(4) The charge shall not be referred to a general court except upon the legal determination (a) that a thorough investigation has been made, (b) that the charge is legally sufficient, and (c) that the evidence is prima facie sufficient to sustain it.

"(5) The summary court by reason of its importance in the field of justice and discipline-for by it men are frequently started on the road to ruin - is required to be an officer specially selected for sanity of judgment and judicial temperament.

"(6) In order to establish trial procedure according to law, the 
special and general courts are to be provided with a judge advocate skilled in the law, with a relation to the court like that which the judge usually has to a jury.

"(7) The right to counsel is established beyond qualification, and ample provision is made for the procurement of competent counsel, both civil and military. Provision is also made for the assignment of a specially qualified officer to prosecute in the name of the United States.

"(8) Membership of the court is fixed by law instead of governed by the present wide discretion of the appointing authority; the special court to consist of three and the general court of eight members.

"(9) It is provided, in the case of the trial of a soldier, that three soldiers be on the membership of a general court and one on a special court.

"(ro) In addition to a challenge for cause, peremptory challenges are authorized, as well also as challenges to the array which are rendered available through affidavits of prejudice. The peculiarities of the military community are demonstrably such as to require this liberalization of the right of challenge.

"(II) Three-fourths of the members of a general court and twothirds of the members of a special court must concur in a finding of guilty.

"(I2) The court and the judge advocate shall perform their functions independently of the appointing or any other authority; they shall be answerable only to their oaths and the law of the land, subservient to no military commander.

"(I3) No action can be taken to affect the lawful judgments of courts except by way of pardon, mitigation, remission, and suspension operating to the benefit of the accused.

"(I4) Trial courts, notwithstanding the legal control of the proceedings herein provided, will commit errors which will be conceded to be such in the light of more deliberate consideration. The Court of Military Appeals, composed normally of civilian judges, is created for the correction of prejudicial errors of law committed in those serious cases resulting in sentences of death, dismissal, dishonorable discharge, and confinement for more than six months.

"(I5) The Court of Military Appeals is also given a retrospective jurisdiction to review and revise the judgments of courts-martial in the most serious cases tried during the War; this because clemency at best is inadequate to correct unjust convictions and almost completely fails in the face of an unsympathetic attitude on the part of the military authorities.

"(I6) Offenses are defined and no longer left to the uncertain conception as to the unwritten law military entertained by men unskilled in law; penalties are legislatively prescribed within reasonable limits and not left to be fixed by military command....

"(I7) The Bill establishes legal guidance of court proceedings from beginning to end and penalizes non-compliance."

\section{$\mathrm{V}$}

The new code properly administered will achieve its declared purpose "to establish military justice." It accepts the "general principles" and for the most part the "specific provisions" of the bill proposed by those who insisted on reform and so ably sponsored by Senator Chamberlain 
in the upper House and Representative Royal Johnson in the lower, as the following salient features of the act, numbered to correspond to the "specific provisions" of the bill, will show:

(I) Enlisted men are placed on a parity with commissioned officers in respect of the right to prefer charges, and all charges must be verified by affidavit. (A. W. 70. $)^{14}$

(2) A preliminary judicial investigation of all charges is required, at which full opportunity shall be given the accused to call witnesses in his own behalf and to cross-examine all witnesses appearing against him, whenever they are available. (A. W. 70. $)^{15}$

(3) (a) Commanding officers are authorized to dispose of minor offenses without resort to court-martial. (A. W. I04.) ${ }^{16}$

(b) Reference of charges to a staff judge advocate for consideration and advice is required before directing trial. (A. W. 7o.) ${ }^{\mathbf{1 7}}$

(c) Inferior courts may be preferred ${ }^{18}$ rather than general courtsmartial, whenever practicable, and the jurisdiction of inferior courts is restated for the purpose. (A. W. I2, I3, I4.) ${ }^{10}$

(4) A judicial investigation and a report by the staff judge advocate as to the sufficiency of the charges and of the evidence are mandatorily required (A.W. 70) ${ }^{20}$

(5) The convening authority shall appoint upon all courts-martial those officers best qualified by reason of age, training, experience, and judicial temperament. (A. W. 4.) $)^{21}$

(6) A "law member" is provided for every general court-martial with power to rule upon all interlocutory questions subject to an appeal to the court, except as to rulings on the admissibility of evidence, which are final. (A. W. 8, 3I.) ${ }^{22}$

(7) A defense counsel with one or more assistants is required to be appointed for each trial, thus placing the defense upon a footing with the prosecution, and civil counsel as well as military is expressly authorized. (A. W. II, I7.) $)^{23}$

( 8 and 9) Not adopted, the latter being regarded as "entirely too radical."

(IO) A single peremptory challenge is authorized. (A. W. I8.) ${ }^{24}$

(II) All convictions and sentences were formerly determined by a majority vote; the new code requires a two-thirds vote, except that capital convictions and death sentences require unanimity and sentences of life imprisonment or confinement for more than ten years require threefourths. (A. W. 43. $)^{25}$

(I2) There are express prohibitions (a) against reconsideration of an acquittal, and (b) against increasing the sentence in any adjudication

\footnotetext{
${ }^{14}$ Act of June 4, r920 (4I Stat. at L. 759, 802).

${ }^{15}$ Ibid.

${ }^{10}$ Ibid. 808. A Manual for Coirts Martial (I921) sec. $336 \mathrm{a}$ advises the disposition of minor offenses without resort to court-martial; and sec. $76 \mathrm{a}$ advises reference to a minor court if the offenses are beyond the disciplinary power of commanding officers.

${ }^{17}$ Act of June 4, I920 (4I Stat. at L. 759, 802).

${ }^{18} \mathrm{~A}$ Manial for Courts Martial ( $\left.192 \mathrm{I}\right)$ sec. 78 requires such preference.

${ }^{30}$ Act of June 4, I920 (4I Stat. at L. 7.59, 789).

${ }^{20} \mathrm{Ibid} .802$.

${ }^{21}$ Ibid. 788.

22 Ibid. 788, 793 .

${ }^{23}$ Ibid. $789,790$.

24 Ibid. 790.

${ }^{25}$ Ibid. 795 , et seq.
} 
or proceeding in review. (A. W. 40 ) $;^{26}$ there are other requirements of, and safeguards for, judicial independence throughout the act.

(I3) All is required by A. W. 40.27

(I4) There is established a system of appellate review of all general courts-martial by tribunals composed of judge advocates, and provision is made for new trials in proper cases. (A. W. $501 / 2.)^{28}$

(I5) Not adopted, the pardoning power being relied upon as an "adequate remedy."

(I6) The offenses are somewhat better defined and discretionary punishments must not exceed a maximum prescribed by the President. (A. W. $45,42,4 \mathrm{~T}$.) $)^{20}$

(I7) Punishment is prescribed for non-compliance with the code and abuse of power by those in military authority, especially in the matter of the unnecessary holding of an accused in arrest or confinement awaiting trial or of directing trial without the required preliminary investigations. (A. W. 7O.) ${ }^{30}$

\section{VI}

The administration of the new code, by reason either of uncontrollable circumstances or a lack of sympathy-apparently the latter-has not been in accord with the letter, spirit or purpose of this highly remedial legislation. That this is so is observable generally, and particularly in respect of the essential requirements of the "Preliminary Investigation and the qualifications of the Law Member." The administrative, ex parte investigation of the Inspector-General's department seems, to a great extent, to take the place of the judicial investigation required by the statute and largely to control the decision as to whether the accused should be tried or not. Again, the legal correctness of the trial depends upon the qualifications of the judge-the law member. The statute requires that the law member "shall be an officer of the Judge Advocate General's department, except that when an officer of that department is not available for the purpose, the appointing authority shall detail instead an officer of some other branch of the service selected by the appointing authority as specially qualified to perform the duties of law member." It is to be noted that the statute makes no such requirement in respect of the trial judge advocate (the prosecuting attorney). And yet the available facts show that courts-martial are rather generally organized with an officer of the Judge Advocate General's department appointed as trial judge advocate and as law member an officer from another branch of the service who cannot claim nor pretend to have the slightest special qualifications. That is, a lawyer is usually found to be more "available" as prosecutor than as judge.

These and like administrative laches should be cured administratively; and certainly the remedy should not be made to wait for the exigency that necessitates legislative action.

\begin{tabular}{lll}
\hline${ }^{26}$ Ibid. 795. & ${ }^{27}$ Ibid. 795. & ${ }^{2}$ Ibid. 797, et seq. \\
${ }^{20}$ Ibid. 796, 795. & ${ }^{30}$ Ibid. 802.
\end{tabular}

